\title{
PEMANFAATAN TEPUNG SILASE USUS AYAM SEBAGAI SUBSTITUSI TEPUNG IKAN DALAM FORMULASI PAKAN BENIH PATIN SIAM (Pangasius hypophthalmus)
}

\section{Utilization of Chicken Intestine Silage Meal as a Substituted of Fish Meal in Feed Formulation of Catfish Fry (Pangasius hypophthalmus)}

\author{
Tri Sukma ${ }^{1}$, Yulisman ${ }^{1 *}$, dan Mirna Fitrani ${ }^{1}$ \\ ${ }^{1}$ Program Studi Akuakultur, Fakultas Pertanian Universitas Sriwijaya, Palembang \\ *yul_cancer@yahoo.com
}

\begin{abstract}
Abstrak
Permintaan terhadap tepung ikan sebagai sumber protein pakan meningkat sejalan dengan bertambahnya kegiatan budidaya ikan, sehingga perlu adanya sumber protein alternatif untuk mengurangi penggunaan tepung ikan. Bahan yang dapat digunakan sebagai sumber protein alternatif yaitu tepung silase usus ayam. Tujuan penelitian ini menentukan persentase tepung silase usus ayam untuk mensubstitusi tepung ikan dalam formulasi pakan benih patin siam dilihat dari pertumbuhan dan efisiensi pakan. Penelitian telah dilaksanakan pada bulan Juni- Juli 2014 di Laboratorium Budidaya Perairan, Program Studi Akuakultur, Fakultas Pertanian, Universitas Sriwijaya. Metoda penelitian menggunakan Rancangan Acak Lengkap dengan enam perlakuan dan tiga ulangan (A: pakan komersil, B: 0\% tepung silase usus ayam dan 100\% tepung ikan, C: $25 \%$ tepung silase usus ayam dan $75 \%$ tepung ikan, D: $50 \%$ tepung silase usus ayam dan 50\% tepung ikan, E: $75 \%$ tepung silase usus ayam dan $25 \%$ tepung ikan, F: $100 \%$ tepung silase usus ayam dan $0 \%$ tepung ikan). Hasil penelitian diketahui pemanfaatan tepung silaseusus ayam berpengaruh nyata terhadap pertumbuhan dan efisiensi pakan namun tidak berpengaruh nyata terhadap kelangsungan hidup benih patin siam. Pemanfaatan tepung silase usus ayam dapat mensubstitusi $100 \%$ tepung ikan dalam formulasi pakan benih patin siam. Selama penelitian kualitas air masih pada kisaran optimal untuk pemeliharaan benih patin siam.
\end{abstract}

Kata kunci: benih patin siam, tepung silase usus ayam, substitusi, pertumbuhan, efisiensi pakan

\section{Abstract}

The demand of fish meal as a protein source of feed increases with the increasing of fish culture activities, so this activities needed alternative protein sources to reduce the use of fish meal. The feed ingredient can be used as an alternative protein source is chicken intestine silage meal. The purpose of this research were to determine the percentage of chicken intestine silage meal to substitute fish meal in feed formulation of catfish fry based on the growth and feed efficiency. This research was conducted in June-July 2014 in the Laboratory of Aquaculture, Aquaculture Program, Faculty of Agriculture, Sriwijaya University. Research methods using Completely Randomized Design with six treatments and three replications (A : commercial feed, B: 0\% chicken intestine silage meal and 100\% fish meal, C: $25 \%$ chicken intestine silage meal and $75 \%$ fish meal, D: $50 \%$ chicken intestine silage meal and 50\% fish meal, E: $75 \%$ chicken intestine silage meal and 25\% fish meal, F: $100 \%$ chicken intestine silage meal and $0 \%$ fish meal). Results showed the utilization of chicken intestine silage meal significant effect on growth and feed efficiency, but not significant on survival catfish fry. Utilization of chicken intestine silae meal could substitute $100 \%$ fish meal in feed formulation of catfish fry. During the study the water quality is still at normal level for the maintenance of catfish fry.

Keywords : catfish fry, chicken intestine silage meal, substituted, growth, feed efficiency

\section{PENDAHULUAN}

Patin siam (Pangasius hypophthalmus) merupakan ikan dari famili pangasidae. Prospek patin, baik di pasar domestik maupun untuk ekspor, sangat besar. Harga ikan patin untuk ekspor dengan berat ratarata $500 \mathrm{~g}$ per ekor sebesar Rp 15.000 (Roesfitawati, 2013). Harga ikan patin hidup di Indonesia berada di kisaran Rp12.000-14.000 per kg (Ratri, 2014). Kebutuhan ikan patin terus meningkat tajam. Produksi ikan patin tahun 2013 sebesar 61.215 ton dan ditargetkan tahun 2014 naik dua kali lipat yaitu sebesar 117.840 ton (Pusat Data Statistik dan Informasi, 2014). 
Berdasarkan prospek pasar yang menjanjikan tersebut, maka perlu dilakukan budidaya patin yang lebih intensif. Produksi ikan secara intensif bergantung pada ketersediaan pakan baik kualitas maupun kuantitas. Kualitas pakan sangat ditentukan oleh bahan penyusun pakan, diantaranya tepung ikan untuk sumber protein hewani. Tepung ikan merupakan sumber protein utama yang digunakan oleh industri pakan ikan (Abdiguna et al., 2013).

Bergantungnya sumber protein utama dalam pakan pada tepung ikan tentu akan menyebabkan ketersediaan tepung ikan semakin terbatas. Selanjutnya seiring dengan semakin menurunnya produksi perikanan tangkap, maka ketersediaan tepung ikan sebagai komponen penghasil pakan juga menurun (Yustianti et al., 2013). Oleh karena itu perlu adanya sumber protein alternatif untuk mengurangi penggunaan tepung ikan dalam pakan.

Bahan pakan yang dapat digunakan sebagai sumber protein alternatif adalah usus ayam hasil limbah pemotongan ayam. Usus ayam memiliki kelebihan untuk dijadikan bahan pakan, yaitu mudah diperoleh dan memiliki kandungan nutrisi yang cukup baik, sedangkan kelemahannya menurut Nugroho (2011) adalah penyimpanan pakan limbah rumah pemotongan ayam lebih sulit dan tidak tahan lama karena mudah membusuk.

Oleh karena itu perlu adanya teknologi pengolahan lebih lanjut terhadap usus ayam, yaitu menjadi silase. Menurut Yunizal (1986) dalam Probosasongko (2003), silase ikan yang dibuat dengan menambahkan 3,5\% campuran asam formiat dan propionat 1:1 dapat disimpan lebih dari 6 bulan tanpa mengalami penurunan kualitas bahan.

Proses pembuatan silase akan menghidrolisis protein (polipeptida) menjadi lebih sederhana (peptida) sehingga lebih mudah dicerna oleh saluran pencernaan ikan, dengan demikian energi yang digunakan dalam proses pencernaan akan berkurang dan kelebihan energinya dapat digu- nakan untuk penambahan protein tubuh dalam proses pertumbuhan (Adelina, 2007).

Hasil penelitian Syah et al. (2006) menunjukkan bahwa penggunaan $20 \%$ tepung silase usus ayam menunjukkan hasil terbaik untuk menggantikan tepung ikan dan diduga lebih dari 20\% penggunaan tepung silase usus ayam telah mencukupi dalam pakan ikan kerapu macan. Silase jeroan ayam dapat menggantikan tepung ikan sampai dengan 20\% dalam pakan buatan ikan nila (Belal et al., 1995).

Hasil penelitian yang dilakukan Hirnawati (2004) berkesimpulan bahwa silase jeroan ikan patin dapat digunakan sampai dengan $75 \%$ dari total tepung ikan dalam formulasi pakan ikan patin.

Informasi mengenai pemanfaatan tepung silase usus ayam untuk mensubstitusi tepung ikan dalam formulasi pakan benih patin siam hingga saat ini belum ada, sehingga perlu dilakukan penelitian.

\section{BAHAN DAN METODE \\ Bahan dan Alat}

Bahan yang digunakan dalam penelitian yaitu benih patin siam (bobot 5,33$6,59 \mathrm{~g}$ ), pelet komersil (protein 30\%), tepung ikan, tepung silase usus ayam, tepung kedelai, dedak halus, tepung tapioka, vitamin mix, asam formiat (kemurnian $85 \%$ ) dan $\mathrm{NaOH}$ (kemurnian $100 \%$ ). Alatalat yang digunakan yaitu kolam terpal ukuran 1 x $0,5 \times 0,5 \mathrm{~m}^{3}$, pH meter, DO meter, termometer, timbangan digital, gelas ukur, blender, ayakan, ember, waring, pencetak pakan.

\section{Metode}

\section{Rancangan Percobaan}

Penelitian ini menggunakan Rancangan Acak Lengkap (RAL) yang terdiri atas enam perlakuan dan tiga ulangan. Perlakuan yang digunakan yaitu kombinasi tepung silase usus ayam dan tepung ikan (dibuat sendiri dari ikan seluang) dalam formulasi pakan benih patin siam dengan acuan $100 \%$ tepung ikan modifikasi persentase tepung ikan dalam penelitian Hirnawati (2004) sebesar 45\% dalam formulasi pakan. 
Adapun perlakuan dalam penelitian sebagai berikut:

$\mathrm{A}=$ Pakan komersil (kontrol)

$\mathrm{B}=0 \%$ tepung silase usus ayam : $100 \%$ tepung ikan

$\mathrm{C}=25 \%$ tepung silase usus ayam : $75 \%$ tepung ikan
$\mathrm{D}=50 \%$ tepung silase usus ayam : $50 \%$ tepung ikan

$\mathrm{E}=75 \%$ tepung silase usus ayam : $25 \%$ tepung ikan

$\mathrm{F}=100 \%$ tepung silase usus ayam : $0 \%$ tepung ikan

\section{Formulasi Pakan}

Tabel 1. Formulasi pakan yang digunakan dalam penelitian

\begin{tabular}{lccccc}
\hline \multirow{2}{*}{ Bahan } & $\mathrm{B}$ & $\mathrm{C}$ & $\mathrm{D}$ & $\mathrm{E}$ & $\mathrm{F}$ \\
\cline { 2 - 6 } & 45 & 33,75 & 22,5 & 11,25 & 0 \\
\hline Tepung Ikan & 0 & 11,25 & 22,5 & 33,75 & 45 \\
Tepung silase usus ayam & 15 & 16 & 21 & 26 & 31 \\
Tepung kedelai & 21 & 20 & 17 & 13 & 10 \\
Dedak halus & 18 & 18 & 16 & 15 & 13 \\
Tepung tapioka & 1 & 1 & 1 & 1 & 1 \\
Vitamin mix & 100 & 100 & 100 & 100 & 100 \\
\hline Jumlah (\%) & 33,49 & 32,14 & 31,90 & 32,63 & 32,76 \\
\hline Protein $(\%)$ & 459,37 & 456,32 & 471,25 & 489,45 & 508,31 \\
\hline GE $($ Kkal/100 g)* & 13,72 & 14,20 & 14,77 & 15,00 & 15,52 \\
\hline GE/P & & & & &
\end{tabular}

Formulasi pakan modifikasi penelitian Hirnawati (2004)

Sumber: $\left.{ }^{*}\right)=$ GE: Gross Energy. Protein: 5,6 Kkal/g protein. Lemak: 9,4 Kkal/g lemak.Karbohidrat: 4,1 Kkal/g karbohidrat (Suprayudi et al., 2013)

\section{Cara Kerja}

Cara kerja dimulai dengan pembuatan silase berdasarkan metode Hirnawati (2004) yang telah dimodifikasi. Usus ayam dibersihkan dari kotoran dan lendir.

Kemudian dimasukkan ke dalam air mendidih selama 3 menit dan dibilas kembali dengan air dingin lalu ditimbang. Selanjutnya usus ayam dicincang atau dipotong-potong.

Usus ayam yang sudah dicincang dipres dan dimasukkan ke dalam ember dan ditambah asam formiat sebanyak 3\% dari bobot usus ayam, kemudian ember ditutup rapat dengan plastik. Setiap hari usus ayam diaduk (pagi, siang, dan sore). Tujuh hari kemudian bahan menjadi bubur dan telah menjadi silase. Silase usus ayam memiliki $\mathrm{pH} 3$, untuk meningkatkan $\mathrm{pH}$ menjadi 7 $\mathrm{NaOH}$ ditambahkan (Adelina, 2007) sebanyak $1 \%$ dari bobot silase usus ayam dan diaduk merata selama 10 menit.

Selanjutnya silase dipres dan dikeringkan dengan dijemur di bawah sinar matahari. Silase yang sudah kering kemudian diblender dan diayak sampai halus menjadi tepung.

Pembuatan pakan dimulai dengan menimbang bahan pakan sesuai formulasi. Selanjutnya bahan pakan dicampur merata dan ditambah air hangat kurang lebih 30\% dari total bahan, kemudian diaduk hingga menjadi adonan yang kalis. Setelah itu adonan dicetak menjadi pelet, kemudian dijemur sampai kering (kadar air kurang lebih $12 \%$ ). Pelet yang sudah kering diambil sampel untuk dilakukan uji proksimat.

Kolam terpal yang digunakan sebagai media pemeliharaan terlebih dahulu dibersihkan dan diisi air sebanyak 160 liter. Selanjutnya aklimatisasi ikan uji dilakukan dengan menebar benih patin siam ke dalam kolam terpal dengan padat tebar 1 ekor per 2 liter (Prasetyo, 2014). Kemudian ikan diberi pakan buatan sesuai perlakuan selama empat hari.

Ikan yang sudah diaklimatisasi dipuasakan selama 24 jam dan dilakukan 
penimbangan bobot dan pengukuran panjang tubuh ikan sebagai data awal. Pengukuran ikan sampel sebanyak 20\% dari jumlah ikan pada setiap kolam. Kemudian ikan dipelihara selama 30 hari.

Selama pemeliharaan ikan diberi makan tiga kali sehari, yaitu pukul 08.00, 12.00 dan 16.00 WIB secara at satiation dan jumlah pakan yang dikonsumsi setiap harinya pada semua perlakuan ditimbang. Selama pemeliharaan dilakukan penyiponan secara kondisional, selanjutnya dilakukan pergantian air sesuai dengan air yang terbuang dari proses penyiponan. Ikan yang mati selama pemeliharaan ditimbang dan diukur panjang tubuhnya.

\section{Parameter pengamatan kelangsungan hidup}

$$
\mathrm{SR}=\frac{\mathrm{Nt}}{\mathrm{No}} \times 100 \%
$$

Keterangan :

$\mathrm{SR}=$ Survival Rate/tingkat kelangsungan hidup (\%)

$\mathrm{N}_{\mathrm{t}}=$ Jumlah ikan yang hidup pada akhir pemeliharaan (ekor)

$\mathrm{N}_{\mathrm{o}}=$ Jumlah ikan pada awal pemeliharaan (ekor)

\section{Pertumbuhan}

$\mathrm{W}=\mathrm{W}_{\mathrm{t}}-\mathrm{W}_{\mathrm{o}}($ Effendie, 2002)

Keterangan :

$\mathrm{W}=$ Pertumbuhan bobot mutlak $(\mathrm{g})$

$\mathrm{W}_{\mathrm{t}}=$ Bobot ikan di akhir pemeliharaan $(\mathrm{g})$

$\mathrm{W}_{\mathrm{o}}=$ Bobot ikan di awal pemeliharaan $(\mathrm{g})$

Keterangan :

$$
\mathrm{L}=\mathrm{L}_{2}-\mathrm{L}_{1} \text { (Effendie, 2002) }
$$

$\mathrm{L}=$ Pertumbuhan panjang mutlak $(\mathrm{cm})$

$\mathrm{L}_{\mathrm{t}}=$ Panjang tubuh ikan akhir $(\mathrm{cm})$

$\mathrm{L}_{\mathrm{o}}=$ Panjang tubuh ikan awal $(\mathrm{cm})$

$\mathrm{SGR}=\frac{\ln \mathrm{Wt}-\ln \mathrm{Wo}}{\mathrm{t}} \times 100 \%$ (Zonneveld et al., 1991)

Keterangan:

$\mathrm{SGR}=$ Specific Growth Rate/laju pertumbuhan spesifik (\%/hari)

$\mathrm{Wt}=$ Bobot akhir biomassa ikan $(\mathrm{g})$

Wo $=$ Bobot awal biomassa ikan (g) $\mathrm{t}=$ Lama pemeliharaan (hari)

\section{Nilai nutrisi tepung silase usus ayam}

Pengukuran kandungan nilai nutrisi tepung silase usus ayam terdiri atas enam parameter yaitu kadar air, abu, serat kasar, lemak, karbohidrat, dan protein. Uji proksimat dilakukan di Laboratorium Bioproses, Jurusan Teknik Kimia, Fakultas Teknik, Universitas Sriwijaya.

\section{Efisiensi pakan dan konversi pakan (Feed Conversion Ratio/FCR)}

$$
\begin{gathered}
E P=\frac{(W t+W d)-W o}{F} \times 100 \% \\
F C R=\frac{F}{(W t+W d)-W o}
\end{gathered}
$$

(Zonneveld et al., 1991)

Keterangan :

$$
\begin{array}{ll}
\mathrm{EP} & =\text { Efisiensi pakan }(\%) \\
\mathrm{FCR} & =\text { Feed Conversion Ratio/konversi pakan } \\
\mathrm{W}_{\mathrm{d}} & =\text { Bobot ikan mati }(\mathrm{g}) \\
\mathrm{Wt} & =\text { Bobot akhir biomassa ikan }(\mathrm{g}) \\
\mathrm{W}_{\mathrm{o}} & =\text { Bobot awal biomassa ikan }(\mathrm{g}) \\
\mathrm{F} & =\text { Pakan yang dikonsumsi }(\mathrm{g})
\end{array}
$$

\section{Kualitas air}

Pengukuran kualitas air dalam penelitian adalah suhu, nilai $\mathrm{pH}$, oksigen terlarut, dan amonia. Pengukuran suhu dilakukan setiap hari yaitu pagi, siang, dan sore. Selanjutnya $\mathrm{pH}$, oksigen terlarut dan amonia diukur setiap satu minggu sekali.

\section{Analisis Data}

Data kelangsungan hidup, pertumbuhan bobot mutlak, panjang mutlak, efisiensi pakan, konversi pakan benih patin siam yang diperoleh dianalisis secara statistik menggunakan analisis sidik ragam taraf kritis 5\%. Jika data berpengaruh nyata dilakukan uji lanjut Beda nyata Jujur (Hanafiah, 2008). Selanjutnya data nilai nutrisi tepung silase usus ayam dan kualitas air dianalisis secara deskriptif. 
HASIL DAN PEMBAHASAN

Kelangsungan Hidup

Tabel 2. Data kelangsungan hidup benih patin siam selama penelitian

\begin{tabular}{cc}
\hline Perlakuan & Kelangsungan Hidup (\%) \\
\hline A & 96,25 \\
B & 94,17 \\
C & 94,17 \\
D & 95,83 \\
E & 95,83 \\
F & 95,00 \\
\hline
\end{tabular}

Berdasarkan analisis sidik ragam taraf kritis 5\% diketahui bahwa pemanfaatan tepung silase usus ayam sebagai substitusi tepung ikan dalam formulasi pakan tidak berpengaruh nyata terhadap kelangsungan hidup benih patin siam. Kelangsungan hidup benih patin siam dalam penelitian ini masih tergolong tinggi, karena menurut Badan Standardisasi Nasional Indonesia (2002) kelangsungan hidup ikan patin yang dipelihara di kolam tanah sebesar $80-95 \%$.

Nilai Nutrisi Tepung Silase Usus Ayam

Tabel 3. Nilai nutrisi tepung silase usus ayam dan tanpa silase (\% bobot kering)

\begin{tabular}{ccc}
\hline Komponen Nutrisi & \multicolumn{2}{c}{ Kandungan } \\
\cline { 2 - 3 } & Tanpa silase & Silase \\
\hline Protein & 33,38 & 37,09 \\
Karbohidrat & 27,42 & 27,46 \\
Lemak & 17,91 & 21,15 \\
Serat Kasar & 7,99 & 4,24 \\
Abu & 13,28 & 9,98 \\
\hline
\end{tabular}

Peningkatan kandungan beberapa nilai nutrisi pada tepung silase usus ayam diduga disebabkan oleh penurunan nilai nutrisi lain seperti serat kasar. Hernaman et al., (2007) menyatakan bahwa penurunan yang terjadi pada serat kasar menyebabkan zat-zat makanan lain seperti protein dan lemak mengalami peningkatan secara proporsional. Menurut Djazuli et al., (1998) dalam Wulandari (2000), dalam suasana asam, bakteri tahan asam misalnya Bacillus
Tingginya kelangsungan hidup benih patin siam setiap perlakuan dalam penelitian ini diduga disebabkan nutrisi pakan yang diberikan cukup untuk menghasilkan energi yang digunakan untuk mempertahankan kelangsungan hidup. Menurut Tyas (2009), energi untuk pemeliharaan tubuh dan aktifitas lain harus terpenuhi terlebih dahulu sebelum energi digunakan untuk pertumbuhan. 
Pertumbuhan

Tabel 4. Pertumbuhan benih patin siam selama penelitian

\begin{tabular}{cccc}
\hline \multirow{2}{*}{ Perlakuan } & \multicolumn{3}{c}{ Parameter } \\
\cline { 2 - 4 } & $\begin{array}{r}\text { Bobot Mutlak (g) } \\
\text { BNJ 5\%=0,25 }\end{array}$ & $\begin{array}{c}\text { Panjang Mutlak (cm) } \\
\text { BNJ 5\%=0,12 }\end{array}$ & $\begin{array}{c}\text { SGR (\%/hari) } \\
\text { BNJ 5\%=0,30 }\end{array}$ \\
\hline A & $3,06^{\mathrm{c}}$ & $1,29^{\mathrm{b}}$ & $1,28^{\mathrm{c}}$ \\
B & $1,89^{\mathrm{a}}$ & $1,05^{\mathrm{a}}$ & $0,74^{\mathrm{a}}$ \\
C & $2,40^{\mathrm{b}}$ & $1,25^{\mathrm{b}}$ & $0,96^{\mathrm{ab}}$ \\
D & $2,88^{\mathrm{c}}$ & $1,28^{\mathrm{b}}$ & $1,21^{\mathrm{bc}}$ \\
E & $2,20^{\mathrm{b}}$ & $1,22^{\mathrm{b}}$ & $0,92^{\mathrm{ab}}$ \\
F & $1,80^{\mathrm{a}}$ & $1,09^{\mathrm{a}}$ & $0,73^{\mathrm{a}}$ \\
\hline
\end{tabular}

Keterangan : Angka-angka yang diikuti oleh huruf superskrip yang sama pada kolom yang sama berarti tidak berbeda nyata pada uji taraf kritis $5 \%$

Berdasarkan analisis sidik ragam taraf kritis 5\% diketahui bahwa pemanfaatan tepung silase usus ayam sebagai substitusi tepung ikan dalam formulasi pakan berpengaruh nyata terhadap pertumbuhan (bobot mutlak, panjang mutlak dan laju pertumbuhan spesifik) benih patin siam. Hasil uji lanjut menggunakan Beda Nyata Jujur taraf kritis 5\% diketahui bahwa benih patin siam yang diberi pakan komersil (perlakuan A) menghasilkan pertumbuhan tertinggi, tetapi tidak berbeda nyata dengan perlakuan D. Sementara pertumbuhan terendah ditunjukkan pada perlakuan B dan tidak berbeda nyata dengan perlakuan $\mathrm{F}$.

Perlakuan A (pakan komersil) menghasilkan pertumbuhan tertinggi karena diduga pakan komersil disusun oleh bahan baku pakan dengan kualitas yang lebih baik dilihat dari komposisi bahan dan profil asam amino. Bahan baku pakan komersil bersumber dari bahan baku impor (Kemendag, 2013 dalam Antika et al., 2014). Meskipun demikian pakan perlakuan D yang terbuat dari bahan baku lokal memberikan hasil pertumbuhan yang tidak berbeda nyata dengan perlakuan

A. Hady (1991) dalam Hirnawati (2004), proses pembuatan silase akan menyebabkan proporsi asam amino bebas lebih tinggi di dalam pakan karena terjadi hidrolisis protein. Hal ini akan memudahkan diabsorbsinya oleh saluran pencernaan ikan (Hirnawati, 2004).

Pola pertumbuhan secara keseluruhan meningkat sejalan dengan penam- bahan tepung silase usus ayam dalam formulasi pakan hingga 50\% (perlakuan D), namun mengalami penurunan pertumbuhan pada penambahan lebih dari $50 \%$. Hal ini menunjukkan bahwa batas optimum penambahan tepung silase usus ayam hanya sampai dengan 50\% dan apabila lebih dari $50 \%$, diduga menyebabkan kandungan asam amino bebas dalam pakan melebihi batas optimum kemampuan benih patin siam untuk memanfaatkan asam amino tersebut.

Sebaliknya rendahnya pertumbuhan pada perlakuan $\mathrm{F}$ diduga kandungan asam amino bebas terlalu tinggi melebihi batas kemampuan absorbsi saluran pencernaan benih patin siam. Hirnawati (2014), kadar asam amino bebas semakin tinggi sejalan dengan proporsi silase dalam pakan, namun jumlah asam amino bebas yang terlalu tinggi akan menyebabkan absorbsi asam amino dalam jumlah besar dan dalam waktu yang singkat sehingga dapat melewati batas kapasitas sintesis protein tubuh. Akibatnya asam amino yang berlebih akan dikatabolisme. Selanjutnya menghasilkan retensi protein dan laju pertumbuhan yang rendah pula.

Disisi lain Perlakuan F memiliki kandungan lemak tertinggi sejalan dengan penambahan tepung silase usus ayam dalam pakan. Syamsunarno (2008), peningkatan lemak menyebabkan penurunan konsumsi makanan ikan sehingga menyebabkan penurunan pertumbuhan. 
Efisiensi Pakan dan Konversi Pakan (Feed Convertion Ratio/FCR)

Tabel 5. Efisiensi pakan dan konversi pakan benih patin siam selama penelitian

\begin{tabular}{ccc}
\hline \multirow{2}{*}{ Perlakuan } & \multicolumn{2}{c}{ Kandungan } \\
\cline { 2 - 3 } & Tanpa silase & Silase \\
\hline A & $66,93^{\mathrm{c}}$ & $1,49^{\mathrm{ab}}$ \\
B & $42,09^{\mathrm{a}}$ & $2,38^{\mathrm{d}}$ \\
C & $56,65^{\mathrm{b}}$ & $1,77^{\mathrm{bc}}$ \\
D & $70,02^{\mathrm{c}}$ & $1,43^{\mathrm{a}}$ \\
E & $53,32^{\mathrm{b}}$ & $1,89^{\mathrm{c}}$ \\
F & $44,09^{\mathrm{a}}$ & $2,27^{\mathrm{d}}$ \\
\hline
\end{tabular}

Keterangan : Angka-angka yang diikuti oleh huruf superskrip yang sama pada kolom yang sama berarti tidak berbeda nyata pada uji taraf kritis 5\%

Berdasarkan analisis sidik ragam taraf kritis $5 \%$ diketahui bahwa pemanfaatan tepung silase usus ayam sebagai substitusi tepung ikan dalam formulasi pakan berpengaruh nyata terhadap efisiensi pemanfaatan pakan benih patin siam. Hasil uji lanjut menggunakan Beda Nyata Jujur taraf kritis $5 \%$ diperoleh bahwa pemanfaatan pakan oleh benih patin siam yang lebih efisien (nilai efisiensi pakan tinggi dan konversi pakan rendah) ditunjukkan pada perlakuan D dan perlakuan A (pakan komersil). Sementara pemanfaatan pakan oleh benih patin siam yang kurang efisien (nilai efisiensi pakan rendah dan konversi pakan tinggi) ditunjukkan pada perlakuan $\mathrm{B}$ dan perlakuan F.

Tingginya efisiensi pakan pada perlakuan A (pakan komersil) diduga disebabkan pakan komersil yang memiliki kualitas pakan yang tinggi. Menurut Haryati et al., (2010), nilai efisiensi pemanfaatan nutrisi menentukan kualitas suatu pakan, semakin besar nilai efisiensi pemanfaatan nutrisi, semakin tinggi kualitas pakannya. Demikian juga perlakuan D menunjukkan pemanfaatan pakan yang efisien. Hal ini diduga kandungan silase dalam formulasi pakan menyebabkan ketersediaan nutrisi pakan lebih sederhana dan dalam jumlah yang mencukupi. Menurut Adelina (2007), proses pembuatan silase dapat menghidro- lisis protein (polipeptida) menjadi sederhana (peptida) sehingga meningkatkan kemampuan ikan untuk mencerna bahan pakan.

Selanjutnya perlakuan dengan persentase tepung silase usus ayam lebih kecil dan atau lebih besar dari 50\% menyebabkan benih patin siam tidak dapat memanfaatkan pakan yang dikonsumsi dengan baik. Dengan demikian pemanfaatan pakan yang kurang efisien menyebabkan pertumbuhan rendah. Hirnawati (2004) menyebutkan bahwa jumlah asam amino yang terlalu tinggi melewati batas kapasitas sintesis protein tubuh akan menghasilkan retensi protein dan laju pertumbuhan yang rendah.

Penambahan tepung silase usus ayam lebih dari $50 \%$, juga meyebabkan kandungan lemak dalam pakan semakin tinggi dan energi pakan meningkat sehingga rasio energi-protein tinggi. Dengan demikian kelebihan energi yang tidak termanfaatkan oleh benih patin siam akan terbuang melalui feses dan proses metabolisme sehingga mengakibatkan pertumbuhan rendah dan efisiensi pakan rendah. Menurut NRC (1993) dalam Pramono et al., (2007), keberadaan tingkat energi yang optimum dalam pakan sangat penting sebab kelebihan atau kekurangan energi mengakibatkan penurunan laju pertumbuhan. 
Kualitas Air

Tabel 6. Kisaran nilai kualitas air media pemeliharaan benih patin siam

\begin{tabular}{|c|c|c|c|c|c|c|c|c|}
\hline \multirow{2}{*}{\multicolumn{2}{|c|}{ Parameter }} & \multicolumn{6}{|c|}{ Perlakuan } & \multirow[t]{2}{*}{$\begin{array}{c}\text { Kisaran } \\
\text { Optimum }\end{array}$} \\
\hline & & A & $\mathrm{B}$ & $\mathrm{C}$ & $\mathrm{D}$ & $\mathrm{E}$ & $\mathrm{F}$ & \\
\hline \multirow{2}{*}{$\begin{array}{l}\text { Suhu } \\
\left({ }^{0} \mathrm{C}\right)^{1}\end{array}$} & Awal & $26-28$ & $26-27$ & $26-28$ & $26-28$ & $26-27$ & $26-28$ & \multirow{2}{*}{$25-30$} \\
\hline & Akhir & $26-27$ & $26-28$ & $26-28$ & $26-28$ & $26-27$ & $26-28$ & \\
\hline \multirow{2}{*}{$\mathrm{pH}^{1}$} & Awal & $6,7-6,7$ & $6,7-7,1$ & $6,7-7,1$ & $6,8-7,0$ & $6,8-7,1$ & $6,7-6,8$ & \multirow{2}{*}{$6,5-8,5$} \\
\hline & Akhir & $6,5-6,7$ & $6,5-6,6$ & $6,5-6,6$ & $6,5-6,5$ & $6,5-6,5$ & $6,5-6,6$ & \\
\hline \multirow{2}{*}{$\begin{array}{c}\mathrm{DO} \\
\left(\begin{array}{c}\mathrm{mg} \cdot \mathrm{L}^{-} \\
1\end{array}\right)^{2}\end{array}$} & Awal & $\begin{array}{c}5,87- \\
6,01\end{array}$ & $\begin{array}{l}5,71- \\
5,92\end{array}$ & $\begin{array}{l}5,62- \\
6,05\end{array}$ & $\begin{array}{l}5,91- \\
6,04\end{array}$ & $\begin{array}{c}5,91- \\
6,11\end{array}$ & $\begin{array}{l}5,70- \\
5,92\end{array}$ & \multirow{2}{*}{$>4$} \\
\hline & Akhir & $\begin{array}{c}2,03- \\
2,15\end{array}$ & $\begin{array}{l}1,82- \\
2,11\end{array}$ & $\begin{array}{l}1,96- \\
2,13\end{array}$ & $\begin{array}{c}2,06- \\
2,33\end{array}$ & $\begin{array}{l}1,91- \\
2,30\end{array}$ & $\begin{array}{c}2,03- \\
2,08\end{array}$ & \\
\hline \multirow{2}{*}{$\begin{array}{c}\text { Amonia } \\
\left(\mathrm{mg} \cdot \mathrm{L}^{-}\right. \\
\left.{ }^{1}\right)^{2}\end{array}$} & Awal & $\begin{array}{c}0,009- \\
0,014\end{array}$ & $\begin{array}{c}0,009- \\
0,015\end{array}$ & $\begin{array}{c}0,010- \\
0,014\end{array}$ & $\begin{array}{c}0,008- \\
0,012\end{array}$ & $\begin{array}{c}0,008- \\
0,015\end{array}$ & $\begin{array}{c}0,012- \\
0,022\end{array}$ & \multirow[b]{2}{*}{$<0,01$} \\
\hline & Akhir & $\begin{array}{c}0,013- \\
0,019 \\
\end{array}$ & $\begin{array}{c}0,012- \\
0,014\end{array}$ & $\begin{array}{c}0,012- \\
0,016 \\
\end{array}$ & $\begin{array}{c}0,012- \\
0,019\end{array}$ & $\begin{array}{c}0,014- \\
0,019\end{array}$ & $\begin{array}{c}0,013- \\
0,014\end{array}$ & \\
\hline
\end{tabular}

Sumber: 1) $=$ Dianalisa secara insitu, 2) $=$ Dianalisa di Laboratorium Dasar Perikanan, 3) $=$ Badan Standardisasi Nasional Indonesia (2002)

Selama penelitian, data pengukuran kualitas air suhu, $\mathrm{pH}$ dan amonia media pemeliharaan benih patin siam masih dalam kisaran yang optimum untuk kelangsungan hidup dan pertumbuhan benih patin siam. Badan Standardisasi Nasional Indonesia (2002), kisaran suhu yang disarankan yaitu $25-30^{\circ}$, pH 6,5-8,5 dan amonia kurang dari $0,1 \mathrm{mg} . \mathrm{L}^{-1}$.

Oksigen terlarut di akhir pemeliharaan tergolong dibawah kisaran optimum untuk pemeliharaan ikan patin. Badan Standardisasi Nasional Indonesia (2002) menyarankan kandungan oksigen terlarut lebih dari $4 \mathrm{mg} . \mathrm{L}^{-1}$. Menurunnya nilai oksigen terlarut diduga karena tingkat konsumsi oksigen oleh ikan dan bakteri pengurai tanpa diimbangi dengan pemberian aerasi pada media selama pemeliharaan.

Meskipun nilai oksigen terlarut dibawah kisaran optimum yang disarankan SNI, namun pada penelitian ini masih dapat mendukung kelangsungan hidup dan pertumbuhan benih patin siam.

\section{KESIMPULAN DAN SARAN Kesimpulan}

Pemanfaatan tepung silase usus ayam dapat mensubstitusi 100\% tepung ikan dalam formulasi pakan benih patin siam ukuran 5,33-6,59 g. Namun pertumbuhan dan efisiensi pakan benih patin siam tertinggi diperoleh pada perlakuan pakan kombinasi 50\% tepung silase usus ayam dan $50 \%$ tepung ikan.

\section{Saran}

Tepung silase usus ayam dapat diaplikasikan sebagai substitusi tepung ikan sebesar 50\% dalam formulasi pakan benih patin siam.

\section{DAFTAR PUSTAKA}

Abdiguna A., Santoso L., Wardiyanto dan Suparman. 2013. Penggunaan tepung daging dan tulang sebagai alternatif sumber protein hewani pada pakan ikan nila merah (Oreochromis niloticus). J. Rekayasa dan Teknologi Budidaya Perairan. 2(1):192-196.

Adelina. 2007. Pemanfaatan Silase Kepala Udang dan Jeroan Ikan sebagai Pengganti Tepung Ikan dalam Pakan Benih Ikan Lele Dumbo (Clarias gariepinus). Laporan Penelitian (tidak dipublikasikan). Fakultas Perikanan dan Ilmu Kelautan Universitas Riau, Pekanbaru. 
Antika R., Siti H. dan Limin S. 2014. Penggunaan tepung onggok singkong yang difermentasi dengan Rhizopus sp. sebagai bahan baku pakan ikan nila merah (Oreochromis niloticus). J. Rekayasa dan Teknologi Budidaya Perairan. 2(2):280- 284.

Badan Standardisasi Nasional Indonesia. 2002. SNI 01-6483.5-2002: Ikan Patin Siam (Pangasius hypophthalmus) Bagian 5: Produksi Kelas Pembesaran di Kolam. BSNI, Jakarta.

Belal IEH., Owaifeir AA. dan Dosari A. 1995. Replacing fish meal with chicken offal silage in commercial Oreochromis niloticus (L.) feed. Aquaculture Research. 26(11):855858.

Effendie MI. 2002. Biologi Perikanan. Yayasan Pustaka Nusatama, Yogyakarta.

Hanafiah KA. 2008. Rancangan Percobaan Teori dan Aplikasi. Raja Grafindo Persada, Jakarta.

Haryati., Saade E. dan Pranata A. 2010. Pengaruh Tingkat Substitusi Tepung Ikan Dengan Tepung Maggot terhadap Retensi dan Efisiensi Pemanfaatan Nutrisi pada Tubuh Ikan Bandeng (Chanos chanos Forsskal). Laporan Penelitian (tidak dipublikasikan). Fakultas Ilmu Kelautan dan Perikanan Universitas Hasanuddin, Makasar.

Hernaman I., Budiman A. dan Rusmana D. 2007. Pembuatan silase campuran ampas tahu dan onggok serta pengaruhnya terhadap fermentabilitas dan zat-zat makanan. J. Bionatura. 9(2):172183.

Hirnawati R. 2004. Pengaruh Kadar Silase Jeroan Ikan Patin yang pH-nya Dinetralkan dalam Pakan terhadap Pertumbuhan Ikan Patin (Pangasius hypophthalmus). Skripsi (tidak dipublikasikan).
Fakultas Perikanan dan Ilmu Kelautan Institut Pertanian Bogor, Bogor.

Nugroho A. 2011. Evaluasi Teknologi Budidaya yang Memanfaatkan Limbah Rumah Pemotongan Ayam pada Pembesaran Ikan Lele Dumbo (Clarias sp.). Skripsi (tidak dipublikasikan). Fakultas Perikanan dan Ilmu Kelautan Institut Pertanian Bogor, Bogor.

Prasetyo GWD. 2014. Pemanfaatan Tepung Kijing (Pilsbryoconch sp.) sebagai Substitusi Tepung Ikan dalam Formulasi Pakan Ikan Patin Siam (Pangasius hypophthalmus). Skripsi (tidak dipublikasikan). Fakultas Pertanian Universitas Sriwijaya, Indralaya.

Probosasongko DAM.2003. Pengaruh Kadar Silase Jeroan Ikan Patin yang Berbeda dalam Pakan terhadap Pertumbuhan Ikan Patin (Pangasius hypophthalmus) Ukuran Sejari. Skripsi (tidak dipublikasikan). Fakultas Perikanan dan Ilmu Kelautan Institut Pertanian Bogor, Bogor.

Pramono TB., Dyahruri S. dan Hary PTS. 2007. Optimasi pakan dengan level protein dan energi protein untuk pertumbuhan calon induk ikan senggaringan. J. Protein. 15(2):153157.

Pusat Data Statistik dan Informasi. 2014. Perdagangan perikanan nonkonsumsi capai 1,7 triliun. Siaran Pers KKP. 3 April, halaman 1.

Ratri ME. 2014. Produksi Fillet Ikan Patin Naik 100\%. Berita 2 Januari 2014. http://www.kontan.co.id/, (Diakses 7 Maret 2014).

Roesfitawati. 2013. Ikan Patin Hasil Alam Bernilai Ekonomi dan Berpotensi Ekspor Tinggi. Warta Ekspor Ikan Patin, Kementerian Perdagangan Republik Indonesia. 4 Oktober, Jakarta. halaman 9. 
Suprayudi MA., Burhanudin F. dan Mia S. 2013. Pengaruh suplementasi selenium organik dengan dosis berbeda dalam pakan terhadap kinerja pertumbuhan ikan nila merah (Oreochromis sp.). $J$. Akuakultur Indonesia. 12(1):52-58.

Syah R., Usman., Kabangnga N. dan Makmur. 2006. Penggunaan tepung silase usus ayam dalam pakan pembesaran ikan kerapu macan (Epinephelus fuscoguttatus). Pusat Penelitian dan Pengembangan Perikanan Budidaya. 639:805 (Abstr).

Syamsunarno MB. 2008. Pengaruh Rasio Energi-Protein yang Berbeda pada Kadar Protein 30\% terhadap Kinerja Pertumbuhan Benih Ikan Patin (Pangasius hypophthalmus). Skripsi (tidak dipublikasikan). Fakultas Perikanan dan Ilmu Kelautan Institut Pertanian Bogor, Bogor.

Tyas DKM. 2009. Penggunaan Meat and Bone Meal (MBM) sebagai Sumber Protein Utama dalam Pakan untuk Pembesaran Ikan Nila (Oreochromis niloticus). Skripsi (tidak dipublikasikan). Fakultas Perikanan dan Ilmu Kelautan Institut Pertanian Bogor, Bogor.

Wulandari A. 2000. Evaluasi Nilai Nutrisi Tepung Silase Ikan dengan Metode Kimiawi dan Bahan Pengikat Dedak Padi dan Pollard. Skripsi (tidak dipublikasikan). Fakultas Perikanan dan Ilmu Kelautan Institut Pertanian Bogor, Bogor.

Yustianti., Ibrahim MN. dan Ruslaini. 2013. Pertumbuhan dan sintasan udang vaname (Litopenaeus vannamei) melalui substitusi tepung ikan dengan tepung usus ayam. J. Mina Laut Indonesia. 1(1):93- 103.

Zonneveld N., Huisman EA. dan Boon JH.1991. Prinsip-prinsip Budidaya
Ikan. Gramedia Pustaka Utama, Jakarta. 